[Letter]

\title{
Ni-Fe-Ce Mixed Nano-composite Oxide Catalyst Prepared by Solution-spray Plasma Technique for High Temperature Water-gas-shift Reaction
}

\author{
Keita Watanabe $^{\dagger 1)}$, Shingo Komori ${ }^{\dagger 1)}$, Toshihiro Miyao ${ }^{\dagger 2)}$, Kazutoshi Higashiyama ${ }^{\dagger 2)}$, \\ Hisao Yamashita ${ }^{\dagger 2}$ and Masahiro Watanabe ${ }^{\dagger 2), ~ * ~}$ \\ ${ }^{* 1)}$ Interdisciplinary Graduate School of Medicine and Engineering, University of Yamanashi, \\ 4-4-37 Takeda, Kofu 400-8510, JAPAN \\ ${ }^{\dagger 2)}$ Fuel Cell Nanomaterials Center, University of Yamanashi,
} 6-43 Miyamae, Kofu 400-0021, JAPAN

(Received August 25, 2010)

Catalytic activity and selectivity of $\mathrm{Ni}-\mathrm{Fe}-\mathrm{Ce}$ oxide nano-composites prepared by the solution-spray plasma technique for the high temperature water-gas-shift reaction were investigated. The composite catalyst exhibited higher activity than a commercial $\mathrm{Fe}-\mathrm{Cr}$ catalyst at $673 \mathrm{~K}$. Compared with an $\mathrm{Ni}-\mathrm{Fe}-\mathrm{Al}$ oxide nano-composite prepared by the same method, the $\mathrm{CO}$ methanation reaction was suppressed remarkably, without serious loss of activity for the water-gas-shift reaction.

Keywords: Water-gas-shift reaction, Solution-spray plasma, Fuel cell, Nano composite catalyst, Nickel based catalyst, Chromium free catalyst

Hydrogen for residential polymer electrolyte fuel cell systems is usually produced by natural gas reforming, including the steam reforming of methane, high and low temperature water-gas-shift (WGS) reactions, and preferential $\mathrm{CO}$ oxidation ${ }^{1)}$. In this study, the catalytic activity of novel Ni-based catalysts for the high temperature WGS reaction was investigated. Due to thermodynamic equilibrium limitations, the WGS reaction is usually carried out in two steps, at high and low temperature ${ }^{2)}$. Fe-Cr-based catalysts are widely used for the high temperature WGS reaction. However, it is necessary to develop $\mathrm{Cr}$-free catalysts from the viewpoint of environmental friendliness. Previously, we reported that an Ni-Fe-Al oxide catalyst prepared by the solution-spray plasma (SSP) technique showed high activity for the WGS reaction. Over this catalyst, simultaneously, more than $2 \%$ of methane formed through $\mathrm{CO}$ methanation, which is a side reaction consuming hydrogen ${ }^{3)}$. In this study, Ni-Ce-oxidebased nano-composites prepared by the SSP technique were applied as catalysts for the high temperature
WGS to suppress the CO methanation. The details of the SSP technique were described in our previous report ${ }^{3)}$. The principal advantages of catalysts prepared by the SSP technique are excellent thermal stability and high dispersion of the active species. In this study, the relationship of catalytic activity and selectivity for the WGS with composition of the catalyst was investigated in detail.

A microwave plasma-generation apparatus with flowing $\mathrm{Ar}$ at atmospheric pressure was employed for preparation of catalysts. Aerosols of homogeneously mixed solutions of nickel, iron and cerium nitrates were injected into the plasma flame with Ar carrier by use of the ultrasonic atomizer, and the resulting oxide powder was collected by a water trap. The WGS reactions were performed in a fixed-bed microreactor at atmospheric pressure. The catalyst powder was shaped and sieved into pellets with diameters in the 1.2-2.0 $\mathrm{mm}$ range. Typically, the composition of the feed gas was $15 \% \mathrm{CO}, 10 \% \mathrm{CO}_{2}, 60 \% \mathrm{H}_{2}$ with $\mathrm{N}_{2}$ balance (dry basis); the space velocity (SV) was $10,000 \mathrm{~h}^{-1}$; the steam to carbon ratio was 1.5 . Prior to

\footnotetext{
“噴霧プラズマ法で調製した Ni-Fe-Ce 複合酸化物触媒による高温水性ガスシフト反応”

渡辺圭太 ${ }^{\dagger 1}$ 、小森信吾 ${ }^{11}$ 、宮尾敏広 ${ }^{\dagger 2}$ 、東山和寿 ${ }^{\dagger 2}$ 、山下壽生 ${ }^{\dagger 2}$ 、渡辺政廣 ${ }^{\dagger 2}$ *

11) 山梨大学大学院医学工学総合教育部、400-8510 山梨県甲府市武田 4-4-37

${ }^{\dagger 2}$ 山梨大学燃料電池ナノ材料研究センター、400-0021 山梨県甲府市宮前町 6-43

*Corresponding author, E-mail: m-watanabe@yamanashi.ac.jp
} 
the kinetic measurements, the catalysts were reduced with $\mathrm{H}_{2}$ at $723 \mathrm{~K}$ for $1 \mathrm{~h}$.

Figure 1 shows microscopic observations of the as-prepared SSP-Ni-Fe-Ce oxide nano-composite particles. Figures 1a and $\mathbf{1 b}$ show SEM and corresponding dark field STEM images (DF-STEM), respectively. The shape of the composite particle is close to a true sphere with an average diameter of approximately $1 \mu \mathrm{m}$. The DF-STEM image indicated that the sphere had a large hollow cavity in the center, which is a remarkable feature of the composite synthesized by the plasma technique ${ }^{3)}$. Small particles dispersed on the shell of the sphere are Ni species. The Ni species can work effectively as an active site for the catalytic reaction by means of the unique hollow structure.

Previously, we have reported that Fe content in the $\mathrm{Ni}-\mathrm{Fe}-\mathrm{Al}$ oxide catalyst had a critical effect on its catalytic properties for the WGS reaction ${ }^{3)}$. In this study, the effect of Fe addition to the Ni-Ce catalyst

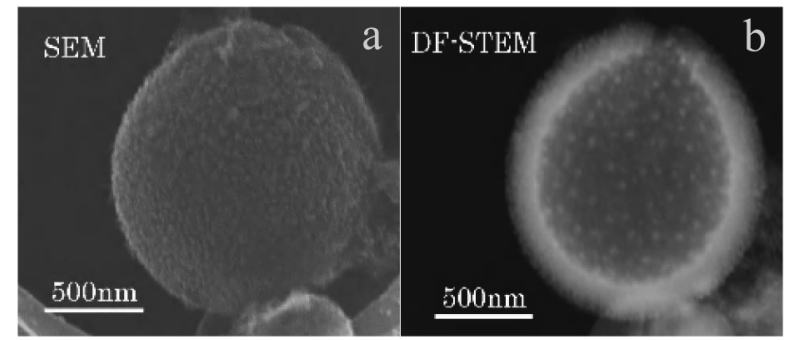

Fig.1 Microscopic Images of As-prepared Ni-Fe-Ce Oxide Nano-composites ( $\mathrm{Fe} / \mathrm{Ni}=1.75)$ : (a) SEM image; (b) DF-STEM image

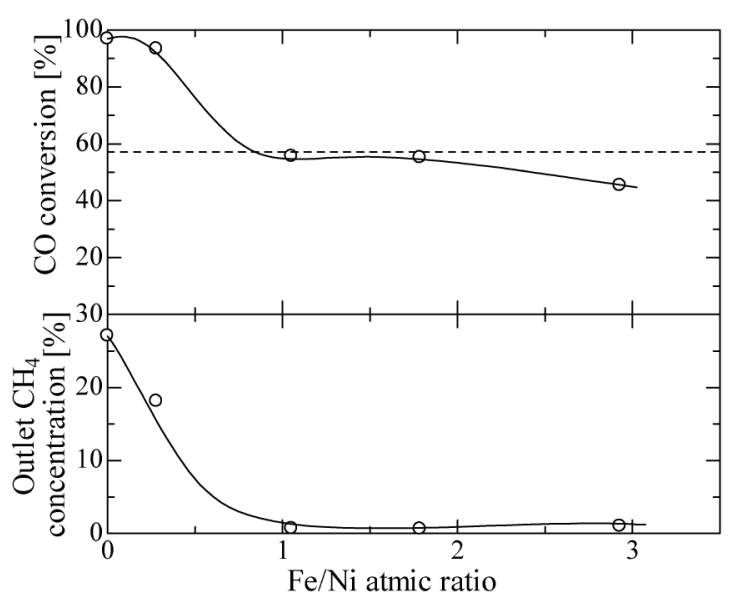

Fig. $2 \mathrm{CO}$ Conversion and $\mathrm{CH}_{4}$ Concentration in the WGS Reaction over Ni-Fe-Ce Catalysts at 673 $\mathrm{K}$ : dashed line, thermodynamic equilibrium concentration of $\mathrm{CO}$ for the WGS reaction at $673 \mathrm{~K}$ was also examined to clarify the applicability of the $\mathrm{Fe}$ addition in the cerium oxide-supported $\mathrm{Ni}$ catalysts. In all cases, the Ce content was adjusted to 36 atom\%. As shown in Fig. 2, when the Fe/Ni ratio was between 1.1 and 1.75, $\mathrm{CO}$ conversion reached the equilibrium value for the WGS reaction, and the outlet $\mathrm{CH}_{4}$ concentration was suppressed below $1 \%$. In contrast, an $\mathrm{Ni}-\mathrm{Ce}$ oxide catalyst without $\mathrm{Fe}$ (corresponding to $\mathrm{Fe} / \mathrm{Ni}$ ratio $=0$ ) exhibited significant methanation activity, and a large amount of hydrogen was consumed. In addition, an $\mathrm{Fe}-\mathrm{Ce}$ oxide catalyst without $\mathrm{Ni}$ (Table 1) exhibited lower activity compared with Ni-containing catalysts. $\mathrm{CO}$ conversion and concentration of $\mathrm{CH}_{4}$ formed via methanation over the Ni-Fe-Al oxide and the $\mathrm{Ni}-\mathrm{Fe}-\mathrm{Ce}$ oxide catalysts $(\mathrm{Fe} / \mathrm{Ni}=1.1)$ are summarized in Table 1 together with those over the commercial $\mathrm{Fe}-\mathrm{Cr}$ catalyst. The Ni-Fe-Ce oxide catalyst exhibited the highest $\mathrm{CO}$ conversion compared with the other catalysts. More noteworthy is the remarkable suppression of methane formation over the $\mathrm{Ni}-\mathrm{Fe}-\mathrm{Ce}$ oxide compared with that over the Ni-Fe-Al oxide. The improvement is possibly due to the metal-support interaction between the Ni species and cerium oxide. No degradation in the catalytic activity was observed for more than several tens of hours during a reaction test employing a $1 \mathrm{~kW}$-practical size reformer. The details will be reported in the near future.

Table $1 \mathrm{CO}$ Conversion and $\mathrm{CH}_{4}$ Concentration over Various Catalysts for the WGS Reaction at $673 \mathrm{~K}$

\begin{tabular}{ccccc}
\hline & Ni-Fe-Ce & Fe-Ce & Ni-Fe-Al & Fe-Cr \\
\hline CO conv. [\%] & 55.7 & 32.1 & 53.2 & 53.8 \\
CH $_{4}$ conc. [\%] & 0.7 & 0.0 & 2.8 & 0.1 \\
\hline
\end{tabular}

\section{Acknowledgement}

This work was financially supported by the New Energy and Industrial Technology Development Organization (NEDO) of Japan.

\section{References}

1) Koryabkina, N., Phatak, A., Ruettinger, W., Farrauto, R., Ribeiro, F., J. Catal., 217, 233 (2003).

2) Ghenciu, F. A., Curr. Opin. Solid State Mater. Sci., 63, 89 (2002).

3) Watanabe, K., Miyao, T., Higashiyama, K., Yamashita, H., Watanabe, M., Catal. Commun., 10, 1952(2009). 